\title{
Nitrogen and carbon losses from dung storage in urban gardens of Niamey, Niger
}

\author{
Martina Predotova $\cdot$ Eva Schlecht . \\ Andreas Buerkert
}

Received: 14 June 2009/Accepted: 2 September 2009/Published online: 19 September 2009

(C) The Author(s) 2009. This article is published with open access at Springerlink.com

\begin{abstract}
Intensive vegetable production in urban and peri-urban agriculture (UPA) of West African cities is characterized by high nutrient inputs. However, little is known about nitrogen $(\mathrm{N})$ and carbon $(\mathrm{C})$ losses in these systems, in particular during the storage of manure, the main organic fertilizer in these systems. We therefore aimed at quantifying gaseous emissions of ammonia $\left(\mathrm{NH}_{3}\right)$, nitrous oxide $\left(\mathrm{N}_{2} \mathrm{O}\right)$, carbon dioxide $\left(\mathrm{CO}_{2}\right)$ and methane $\left(\mathrm{CH}_{4}\right)$ as well as leaching losses of $\mathrm{C}, \mathrm{N}$, phosphorus $(\mathrm{P})$ and potassium (K) from animal manure stored in vegetable gardens of Niamey, Niger. During a first 3.5-month experiment in the hot dry season, cumulative gaseous $\mathrm{N}$ losses, measured with a closed-chamber system, were with $0.11 \mathrm{~g} \mathrm{~kg}^{-1}$ manure DM highest $(P<0.05)$ in the uncovered control treatment accounting for $1.8 \%$ of total manure N. Nitrogen losses decreased by $72 \%$ under plastic sheet roofing and by $50 \%$ under roofing + ground rock phosphate $(\mathrm{RP})$ application
\end{abstract}

M. Predotova · A. Buerkert $(\square)$

Organic Plant Production and Agroecosystems Research in the Tropics and Subtropics, University of Kassel, Kassel, Germany

e-mail: tropcrops@uni-kassel.de; buerkert@uni-kassel.de

E. Schlecht

Animal Husbandry in the Tropics and Subtropics, University of Kassel, Kassel, Germany

E. Schlecht

Georg-August-Universität Göttingen, Göttingen, Germany at $333 \mathrm{~g} \mathrm{~kg}^{-1}$ manure DM. Carbon losses from manure amounted to $73 \mathrm{~g} \mathrm{~kg}^{-1} \mathrm{DM}$ in the control and to $92 \mathrm{~g} \mathrm{~kg}^{-1} \mathrm{DM}$ and $68 \mathrm{~g} \mathrm{~kg}^{-1} \mathrm{DM}$ under roofing and under roofing $+\mathrm{RP}$, respectively. In a second 3.5-month experiment conducted in the rainy season, $\mathrm{C}$ losses from the control were $164 \mathrm{~g} \mathrm{~kg}^{-1}$ manure DM and reduced to 77 and $65 \%$ of the control by roofing and roofing $+\mathrm{RP}$, respectively. Leaching losses during the rainy season were only observed for the unroofed control and averaged $2.1 \mathrm{~g} \mathrm{C}, 0.05 \mathrm{~g} \mathrm{~N}$, $0.07 \mathrm{~g} \mathrm{P}$ and $1.8 \mathrm{~g} \mathrm{~K} \mathrm{~kg}^{-1}$ manure DM.

Keywords Africa - Gaseous emissions ·

Nutrient leaching · Rock phosphate ·

Ruminant manure · Urban agriculture

\section{Introduction}

From 1930-1990 the urban population in West Africa has grown by an annual rate of $4 \%$ and by $202063 \%$ of the total population of West Africa is expected to live in towns (Drechsel et al. 2005). Concomitantly the role of agricultural production within and at the periphery of urban areas has been rapidly rising as it provides food and employment for the urban population. Recent studies have shown that UPA supplies 10-90\% of fresh vegetables, up to $70 \%$ of meat and up to $100 \%$ of eggs on city markets (Maxwell 1995; Madaleno 2000; Cofie et al. 2003; Drechsel et al. 2005). The proportion 
of urban households involved in UPA varies from 10 to 57\% (Ellis and Sumberg 1998; Howorth et al. 2001; Asomani-Boateng 2002; Cofie et al. 2003) and so does production intensity and resource use efficiency. Sometimes, high levels of inputs used in the vicinity of human settlements have been reported to cause serious problems to human health and the environment (Ezedinma and Chukuezi 1999; Howorth et al. 2001; Asomani-Boateng 2002; Matagi 2002; Binns et al. 2003; Bryld 2003; Cofie et al. 2003; Drechsel et al. 2005).

Unless used otherwise, animal dung produced in UPA animal husbandry is an important source of nutrients and $\mathrm{C}$ for urban farmers (Graefe et al. 2008); however, a recent report from sub-Saharan Africa shows that manure use in UPA gardening is accompanied by substantial gaseous and leaching losses of $\mathrm{N}$ (Predotova et al. 2010). According to FAO-IFA (2001) the total nutrient application to African crops and grasslands contributes 12, 9 and $3 \%$ to the global emissions of $\mathrm{N}_{2} \mathrm{O}-\mathrm{N}$, NO-N and $\mathrm{NH}_{3}-\mathrm{N}$, respectively. Proper dung handling may strongly decrease the environmental pollution and improve the nutrient use efficiency at the farm level.

Within the context of a larger effort to increase resource use efficiency in UPA, this study was conducted to quantify gaseous emissions of $\mathrm{C}$ and $\mathrm{N}$ as well as leaching loses of $\mathrm{C}, \mathrm{N}, \mathrm{P}$ and $\mathrm{K}$ from dung heaps in market-oriented gardening systems of a typical Sahelian town and to experimentally test approaches that could decrease such losses.

\section{Materials and methods}

\section{Experimental setup}

The dung storage experiment was conducted in Goudel, an inner-city quarter of Niamey $\left(13.5^{\circ} \mathrm{N}\right.$, $2.1^{\circ} \mathrm{E}, 223 \mathrm{~m}$ a.s.1.), capital city of the Republic of Niger. The local southern Sahelian climate is semiarid, with an average annual precipitation of 400$600 \mathrm{~mm}$ distributed unimodally from June to September; the 30-year average annual rainfall is $542 \mathrm{~mm}$. Daily average temperatures peak at $34^{\circ} \mathrm{C}$ in May and drop to $25^{\circ} \mathrm{C}$ in December (World Climate 2008).

The experiment consisted of two periods of 3.5-month duration each. The first period started with the heaping of dung in the hot dry season (beginning of April 2007), the second dung heaping started at the onset of the rainy season (mid-July 2007). In both periods, 12 dung heaps of $70 \mathrm{~kg}$ fresh mass $(30 \mathrm{~kg} \mathrm{DM})$, consisting of a 1.8:1 w:w mixture of fresh dung from cattle and small ruminants, were subjected to the following treatments: (1) heaps without any cover (treatment $\mathrm{C}$, that is farmer's control with full exposure to sun and rain); (2) heaps shaded and protected from rain by a roof made from a double plastic sheet and mounted on four $0.7 \mathrm{~m}$ high posts (treatment R); and (3) manure homogeneously mixed with finely ground Tahoua RP $(10.3 \% \mathrm{P}$ at $19.3 \%$ solubility in citric acid and $34 \%$ solubility in formic acid; Truong et al. 1978; McClellan and Notholt 1986; van Straaten 2002) at a rate of $333 \mathrm{~g}$ rock powder $\mathrm{kg}^{-1}$ manure DM and roofed as in (2) (treatment RP). All heaps had a base area of $1 \mathrm{~m}^{2}$ and were about $0.5 \mathrm{~m}$ high. Each heap was placed on an individual $1 \mathrm{~m}^{2}$ iron sheet which had a slope of about $2 \%$ to facilitate rainfall-induced run-off during the rainy season. The sheet ended in a gutter from where run-off liquid was drained through a $2 \mathrm{~mm}$ mesh into a 21 collecting container which contained $5 \mathrm{ml}$ of $0.1 \mathrm{M} \mathrm{HCl}$ to minimize $\mathrm{N}$ volatilization. The three treatments were arranged in a completely randomized design with four replications per treatment.

\section{Measurements of nutrient losses}

Gaseous $\mathrm{C}$ and $\mathrm{N}$ emissions from the manure heaps and dung decomposition were determined 7 times during each 3.5 months period, namely at the first 2 days of weeks $1,2,4,6,9,12$, and 15 , while the run-off was assessed whenever it occurred after a rainfall event.

To determine flux rates of ammonia $\left(\mathrm{NH}_{3}\right)$, nitrous oxide $\left(\mathrm{N}_{2} \mathrm{O}\right)$, carbon dioxide $\left(\mathrm{CO}_{2}\right)$ and methane $\left(\mathrm{CH}_{4}\right)$, a closed chamber system composed of a photo-acoustic infrared multi-gas monitor (INNOVA 1312-5, LumaSense Technologies A/S, Ballerup, Denmark; Kauppinen et al. 2004; Zhang et al. 2005) connected by two $0.5 \mathrm{~m}$ long Teflon ${ }^{\circledR}$ inflow and outflow tubes to a PVC cuvette with a diameter of $0.3 \mathrm{~m}$ and height $0.11 \mathrm{~m}$ was used (Predotova et al. 2010). To minimize adhesion of gas molecules to the surface, the inside of the cuvette was coated by a self-adhesive $0.5 \mathrm{~mm}$ Teflon $^{\circledR}$ film (Chemfab Germany GmbH, Cologne, Germany). To ensure 
tight connection with the measured dung surface, the cuvette was fitted to a $0.3 \mathrm{~m}$ wide and $0.06 \mathrm{~m}$ high ring which was firmly pressed about $0.05 \mathrm{~m}$ deep into the dung heap.

The multi-gas monitor was manufacturer-calibrated and set to compensate cross-interferences of gases and water vapor with $\mathrm{NH}_{3}, \mathrm{~N}_{2} \mathrm{O}, \mathrm{CO}_{2}$ and $\mathrm{CH}_{4}$. A sample integration time of $5 \mathrm{~s}$ for each gas was chosen for which the lower detection limits were $200 \mu \mathrm{g} \mathrm{kg}^{-1}$ for $\mathrm{NH}_{3}, 30 \mu \mathrm{g} \mathrm{kg}^{-1}$ for $\mathrm{N}_{2} \mathrm{O}$, $3.4 \mathrm{mg} \mathrm{kg}^{-1}$ for $\mathrm{CO}_{2}$ and $400 \mu \mathrm{g} \mathrm{kg}^{-1}$ for $\mathrm{CH}_{4}$. Inside the cuvette the air humidity and temperature was measured with a thermo-hygrometer (PCE-313 A, Paper-Consult Engineering Group, Meschede, Germany) and the ambient air temperature and humidity was recorded during measurement periods by a HOBO Pro data logger (Model H08-032-08, Onset Corp., Bourne, MA, USA) at 1 min intervals. Each measurement time lasted for two consecutive days for which flux rates were recorded during the coldest (6-8 a.m.) and hottest (1-3 p.m.) part of the day. Measurements were taken once per heap by reading flux rates during a 1 min accumulation period taken during $5 \mathrm{~min}$ on the top of the heap.

Validation measurements with defined pure gases and gas mixtures conducted after the experiment at Staatliche Umweltbetriebsgesellschaft of Saxony (Radebeul, Germany) showed errors for $\mathrm{NH}_{3}, \mathrm{~N}_{2} \mathrm{O}$, $\mathrm{CO}_{2}$ and $\mathrm{CH}_{4}$ of $-13,-12,5$ and $-2 \%$ respectively, resulting in a possible underestimation of $\mathrm{N}$ losses and a slight overestimation of $\mathrm{C}$ losses with our setup.

To determine dung decomposition rates, litter bags made from nylon fibre with a mesh size of $0.2 \mathrm{~mm}$ were filled with $50 \mathrm{~g}$ (fresh weight, corresponding to about $21.4 \mathrm{~g}$ dry matter, DM) of dung, numbered, attached to a string and inserted into the dung heap. On Day 1 of each gas measurement period, one bag from each heap was pulled out, homogenized and frozen $\left(-18^{\circ} \mathrm{C}\right)$ until analysis of DM, organic matter $(\mathrm{OM})$ and N. Dry matter was analyzed by drying the samples at $105^{\circ} \mathrm{C}$ for at least $6.5 \mathrm{~h}, \mathrm{OM}$ by burning at $550^{\circ} \mathrm{C}$ for $8 \mathrm{~h}$ and $\mathrm{N}$ was measured colorimetrically by the salicylate/nitroprusside method (Houba et al. 1995).

The amount of leached liquids was determined immediately after each rainfall by emptying the collection container into a graded volumetric flask.
A sample of $100 \mathrm{ml}$ of the drained liquid was collected into $150 \mathrm{ml}$ flasks and stored frozen $\left(18^{\circ} \mathrm{C}\right)$ until analysis of $\mathrm{N}, \mathrm{P}, \mathrm{K}$ as described by Houba et al. (1995) and of Corg according to Walkley and Black (van Reeuwijk 1993).

Data analysis

Flux rates of $\mathrm{NH}_{3}, \mathrm{~N}_{2} \mathrm{O}, \mathrm{CO}_{2}$ and $\mathrm{CH}_{4}$ missions were calculated by subtracting the gas concentration at the beginning of the accumulation period from the concentration at the end of the accumulation period and dividing the result by the time elapsed during the interval. Small negative emission rates which occasionally occurred during the morning measurements in the second half of each 3.5-month experiment were set to zero (Predotova et al. 2010). To estimate cumulative losses, a sinusoidal distribution of the gaseous emissions was assumed with the highest and lowest fluxes during the hottest and coldest part of the day. To approximate this, the results of the morning and afternoon measurements were averaged for each replicate separately across the 2 day measurement interval and multiplied by the time span to the next measurement period.

$F$-statistics to compare treatment effects on gas emission rates over time were carried out with SPSS 11.5 (Backhaus et al. 2003). To facilitate data interpretation, none of the datasets was transformed even if slight deviations from normal distribution of residuals occurred in some datasets; $F$-values are thus only approximate.

To collect information about UPA farmers' practices of dung management, the experiment was accompanied by structured interviews conducted with 215 farmers located in different quarters of Niamey.

\section{Results}

Seasonal and treatment effects on gaseous emissions

During the hot dry season, the average ambient air temperature at the experimental site was $34^{\circ} \mathrm{C}$ with a maximum of $45^{\circ} \mathrm{C}$ and a minimum of $21^{\circ} \mathrm{C}$. During the rainy season, the temperature averaged $30^{\circ} \mathrm{C}$ (range: $20-39^{\circ} \mathrm{C}$ ). The rainfall in 2007 amounted to 


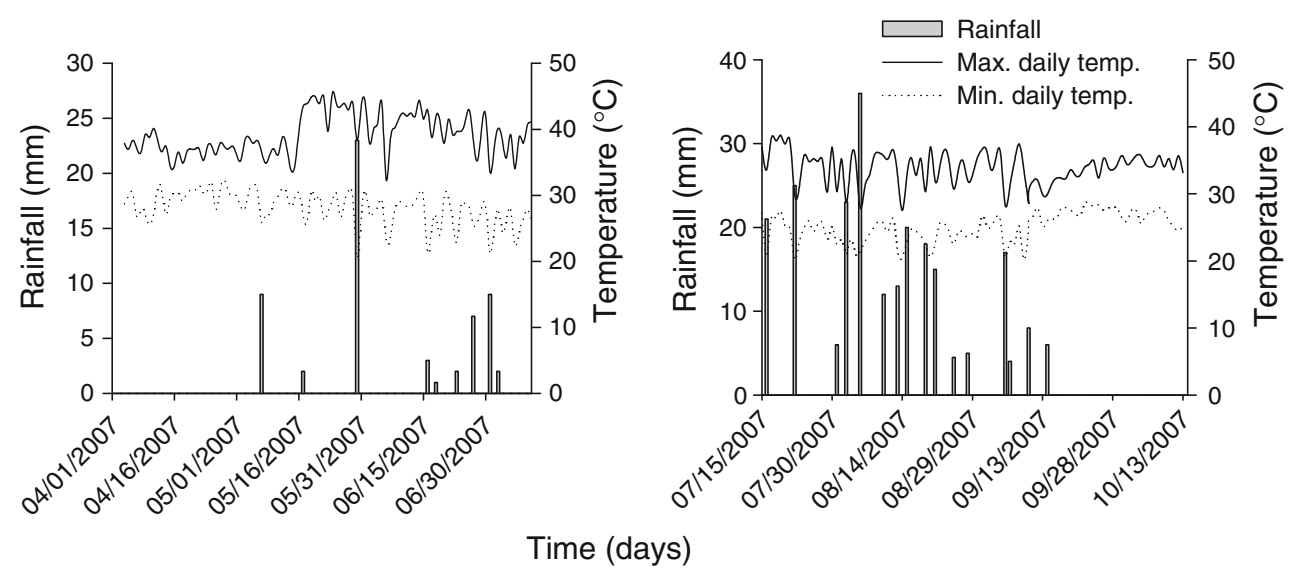

Fig. 1 Daily maximal and minimal temperatures $\left({ }^{\circ} \mathrm{C}\right)$ and rainfall $(\mathrm{mm})$ during the hot dry $($ left $)$ and rainy $($ right $)$ season in 2007 in the Goudel quarter in Niamey, Niger

$371 \mathrm{~mm}$ (Fig. 1) of which $25 \%$ unexpectedly occurred during the first period of the dung storage experiment, with one intensive rain event at the end of May yielding $23 \mathrm{~mm}$.

During the hot dry season the major form of gaseous $\mathrm{N}$ emissions was $\mathrm{NH}_{3}$ of which $49-82 \%$ occurred during the evening the experiment was installed and during the first week of dung storage. Volatilization losses were highest in the $\mathrm{R}$ and $\mathrm{C}$ treatments and occurred especially during afternoons with their high temperatures (Fig. 2). Similarly to $\mathrm{NH}_{3}-\mathrm{N}$, the major portion of the $\mathrm{N}_{2} \mathrm{O}-\mathrm{N}$ losses occurred during the same evening the experiment was installed and the following morning. Fluxes of $\mathrm{CO}_{2}-\mathrm{C}$ and $\mathrm{CH}_{4}-\mathrm{C}$, in contrast, did not differ much between morning and afternoon hours, but the decrease of emission rates over the duration of the experiment was as fast as for N. During the hot dry season between 31 and $43 \%$ of $\mathrm{CO}_{2}-\mathrm{C}$ and $16-21 \%$ of $\mathrm{CH}_{4}-\mathrm{C}$ were lost during the first experimental week.

During the rainy season, $\mathrm{N}$ losses as $\mathrm{NH}_{3}$ and $\mathrm{N}_{2} \mathrm{O}$ peaked immediately after the installation of the experiment. From the second week onwards flux rates were below 0.7 and $0.3 \mathrm{mg} \mathrm{m}^{-2} \mathrm{~h}^{-1}$, respectively (Fig. 3). During the first experimental week $\mathrm{CO}_{2}-\mathrm{C}$ losses amounted to $13-28 \%$ of total $\mathrm{C}$ losses; they were substantially higher during the hot dry than during the rainy season. After an initial peak $\mathrm{CH}_{4}-\mathrm{C}$ emissions decreased slowly over the course of the experiment. Methane losses from control heaps (C) were much higher $(P<0.05)$ than for the two other treatments during weeks 1,4 and 6 .

For treatments $\mathrm{R}$ and $\mathrm{C}$, total $\mathrm{NH}_{3}-\mathrm{N}$ losses during the hot dry season were significantly higher $(P<0.05)$ than during the rainy season (Fig. 4). In the hot dry season, roofing in combination with the addition of RP led to large decreases in $\mathrm{NH}_{3}-\mathrm{N}$ losses as compared to the two other treatments. Total $\mathrm{N}_{2} \mathrm{O}$ $\mathrm{N}$ emissions were similar in both seasons and amounted to 19,18 and $28 \%$ of the total $\mathrm{N}$ losses in treatments $\mathrm{C}, \mathrm{R}$ and $\mathrm{RP}$, respectively. Across all treatments $\mathrm{CO}_{2}-\mathrm{C}$ emissions were significantly higher $(P<0.05)$ in the rainy season than in the hot dry season, reaching cumulative values of $3.8 \mathrm{~kg} \mathrm{CO}_{2}-\mathrm{C}$ $\mathrm{m}^{-2} 106$ days $^{-1}, 3.2 \mathrm{~kg} \mathrm{CO}_{2}-\mathrm{C} \mathrm{m}^{-2} 106$ days $^{-1}$ and $4.9 \mathrm{~kg} \mathrm{CO}_{2}-\mathrm{C} \mathrm{m}^{-2} 106$ days $^{-1}$ for treatments R, RP and $\mathrm{C}$, respectively. Cumulative $\mathrm{CH}_{4}-\mathrm{C}$ losses were with $27.2 \mathrm{~g} \mathrm{CH}_{4}-\mathrm{C} \mathrm{m}^{-2} 106$ days $^{-1}$ twice as high for the untreated control as for R and RP in the rainy season (Fig. 4).

Treatment effects on leaching losses and manure decomposition

Leaching losses occurred only after rainfall events in the unroofed control heaps, which were exposed to the rain. As some unexpected rainfall occurred at the end of the hot dry season, some leaching losses were also recorded in the first period of the experiment. However, cumulative leaching losses were much higher during the rainy than during the hot dry season (Fig. 5). 

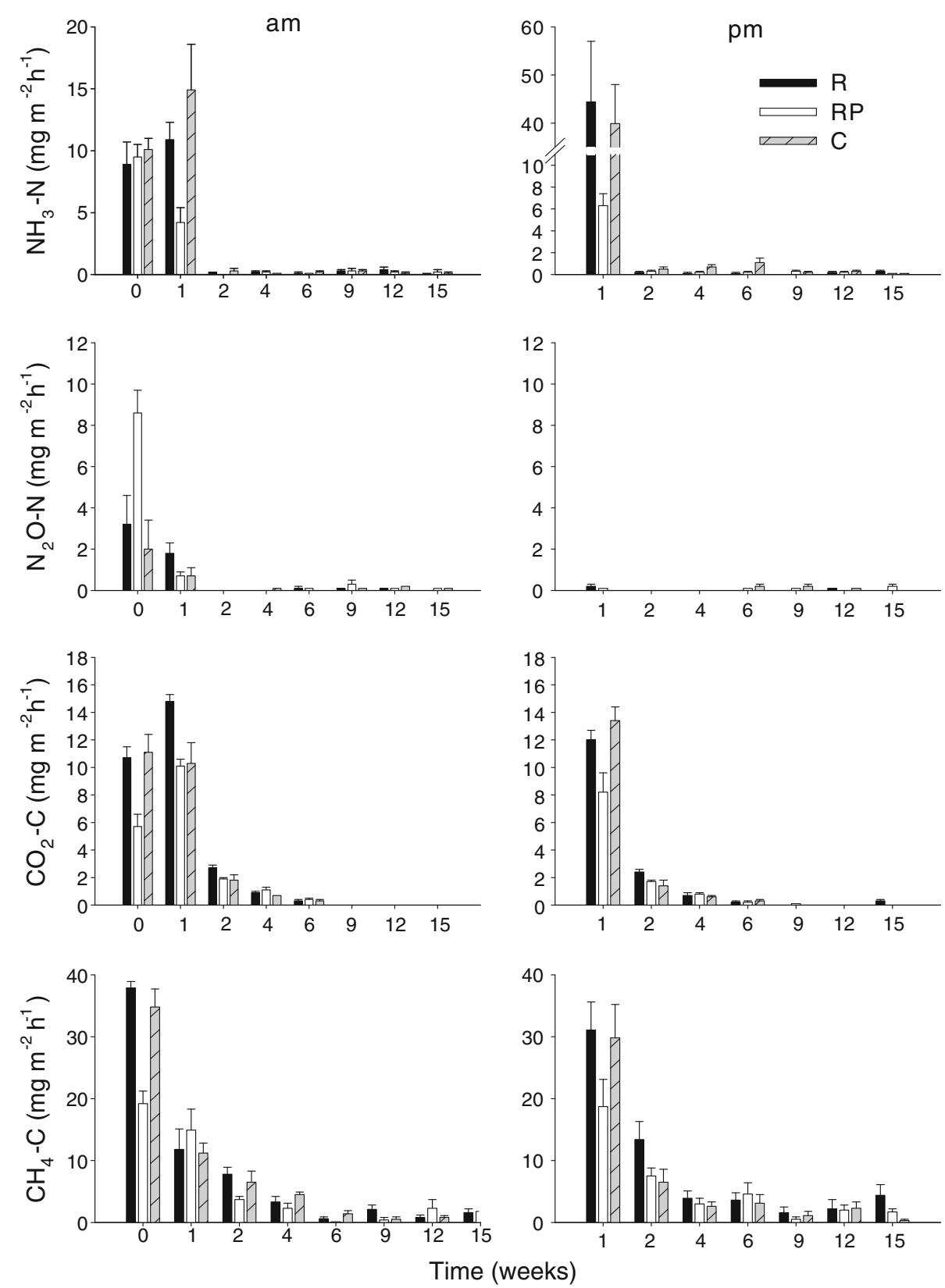

Fig. 2 Gaseous emissions of three dung storage treatments during the hot dry season 2007, Niamey, Niger. Means $(n=8)$ and standard errors from 1 st to 15 th week $(n=4$ for time zero). The bars at time zero illustrate the emissions

The DM content of the manure fresh matter inside the nylon bags increased during the hot dry season (Fig. 6) from an initial $378 \mathrm{~g} \mathrm{~kg}^{-1}$ (R), $470 \mathrm{~g} \mathrm{~kg}^{-1}$ (RP) and $375 \mathrm{~g} \mathrm{~kg}^{-1}(\mathrm{C})$, to $825 \mathrm{~g} \mathrm{~kg}^{-1}, 752 \mathrm{~g} \mathrm{~kg}^{-1}$ and $838 \mathrm{~g} \mathrm{~kg}^{-1}$, respectively. For treatments $\mathrm{R}$ and immediately after installation of the dung heaps in the late evening when ambient air temperatures were more similar to morning than to midday conditions

$\mathrm{RP}$, the drying of the dung heaps was much slower during the rainy season than during the hot dry season. Overall OM decomposition was slow and slightly reduced by RP application (Fig. 6). For all treatments, the $\mathrm{C} / \mathrm{N}$ ratio (Fig. 7) of the dung ranged 

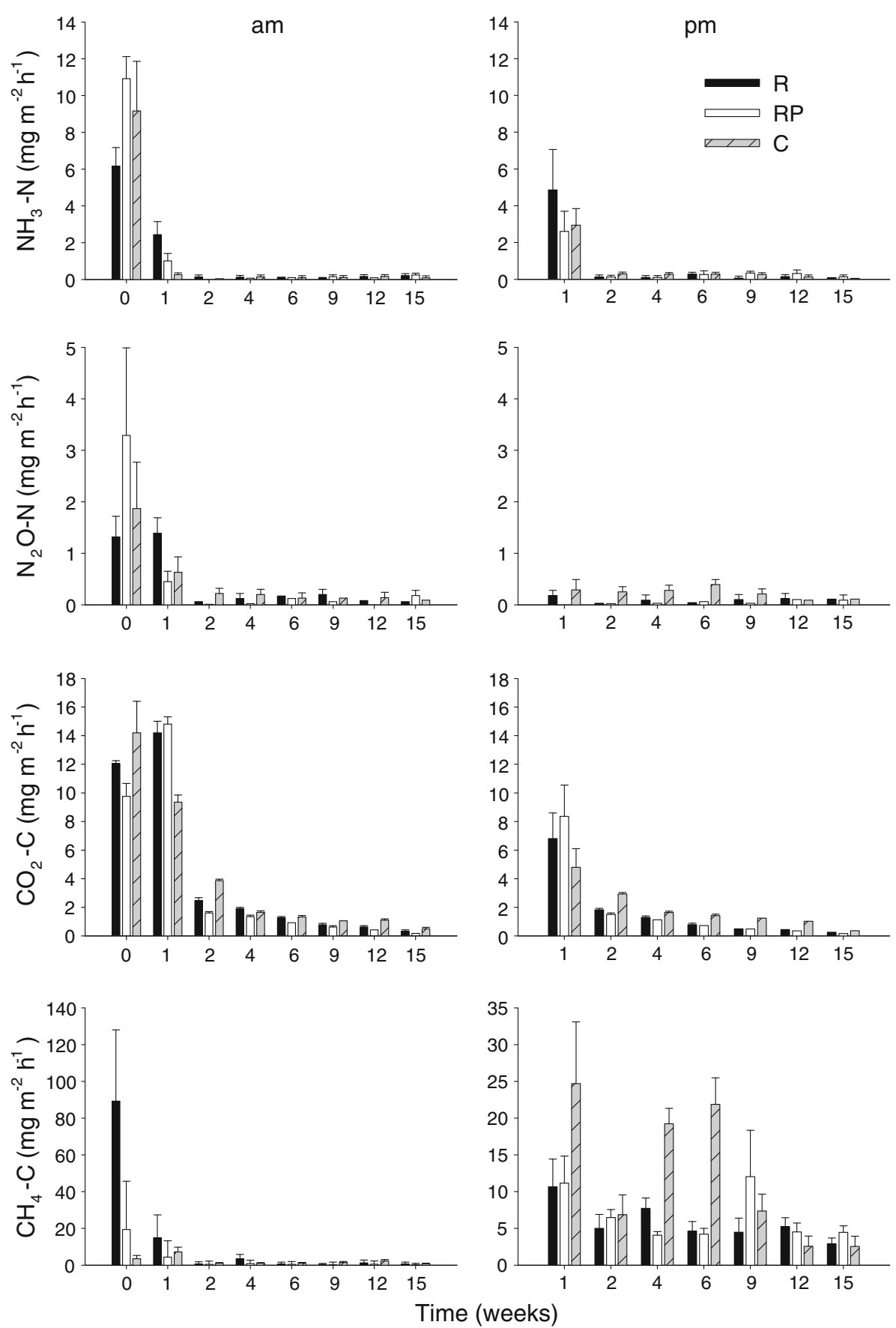

Fig. 3 Gaseous emissions of three dung storage treatments during the rainy season 2007, Niamey, Niger. Means $(n=8)$ and standard errors from 1 st to 15 th week $(n=4$ for time zero). The vertical bars at time zero illustrate the emissions

between 23 and 27 during the hot dry season; the only exception being the initial $\mathrm{C} / \mathrm{N}$ ratio determined for dung mixed with RP. During the 3.5 months of rainy immediately after installation of the dung heaps in the late evening when ambient air temperatures were more similar to morning than to midday conditions

season experimentation, the $\mathrm{C} / \mathrm{N}$ ratio decreased from 30 to 21 in treatment $\mathrm{R}$, from 34 to 24 in treatment $\mathrm{RP}$ and from $28-23$ in treatment $\mathrm{C}$. 


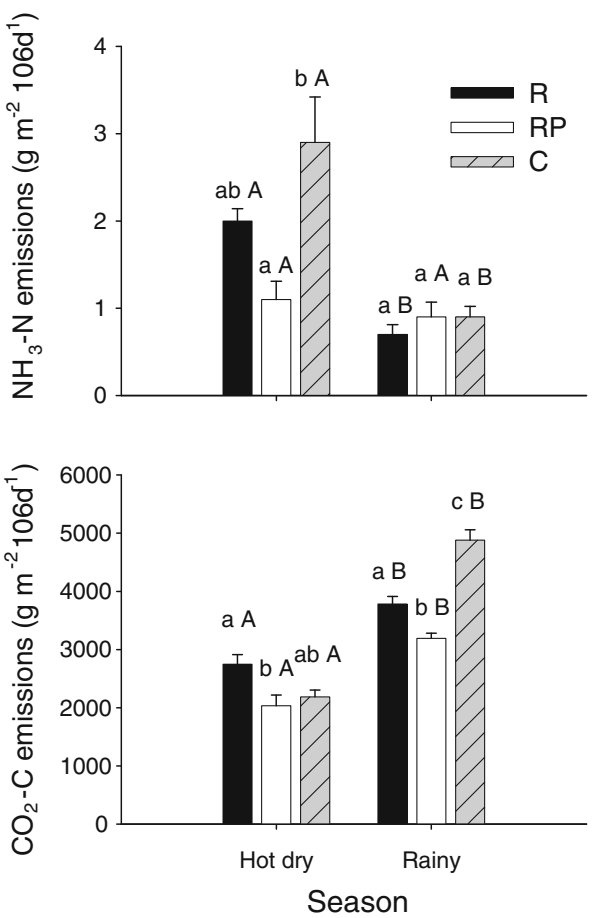

Fig. 4 Total $\mathrm{N}$ and $\mathrm{C}$ losses as $\mathrm{NH}_{3}, \mathrm{~N}_{2} \mathrm{O}$ and $\mathrm{CO}_{2}, \mathrm{CH}_{4}$, respectively, from a dung storage experiment in Niamey (Niger) lasting for 106 days. Data show means $(n=4)$ with their standard errors. Different small letters indicate differences

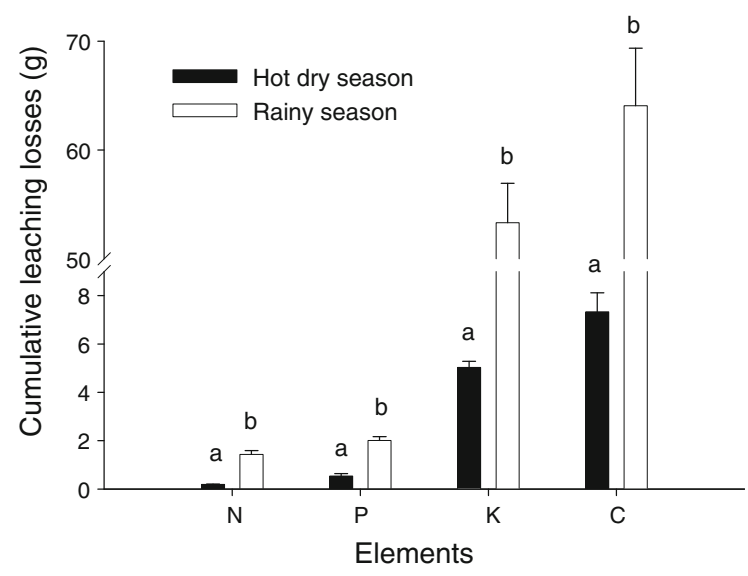

Fig. 5 Cumulative leaching losses from the control treatment of a dung storage experiment conducted in Niamey (Niger) in 2007; data show means $(n=4)$ and standard errors. Different letters indicate differences $(P<0.05)$ between seasons

Farmers' manure storage practices

The results of the interviews showed that most of the UPA farmers (99.5\%) applied purchased or their own
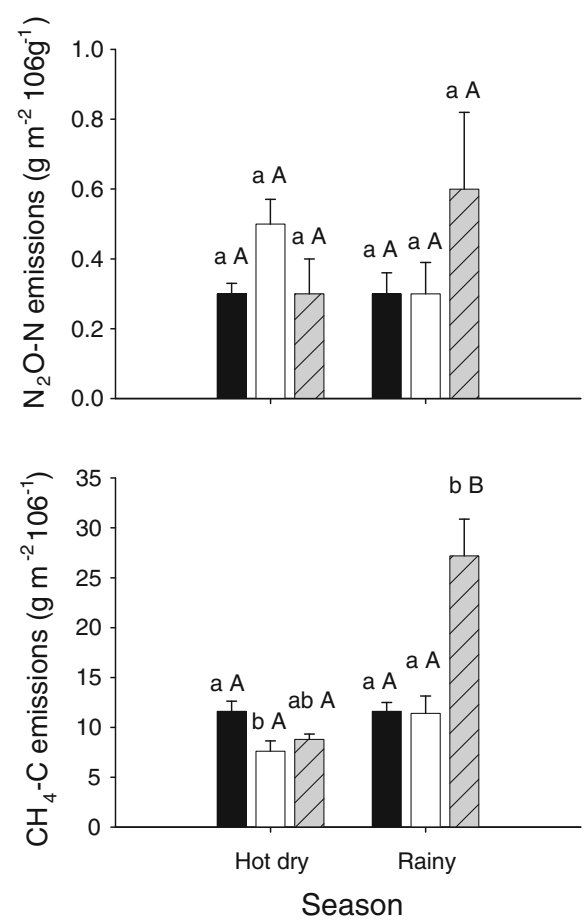

$(P<0.05)$ between treatments within one season whereas different capital letters indicate differences $(P<0.05)$ between seasons for each treatment

animal manure to their fields and gardens; $67 \%$ of the respondents applied mineral fertilizers in addition to manure. The dung was transported to the garden by animal drawn carts (13\%), manually (27\%), by car $(25 \%)$ or by a combination of the former $(35 \%)$, often every two (57\%) or four (31\%) weeks. Almost half of the farmers $(49 \%)$ transported the dung from a distance $<1 \mathrm{~km}$ to the garden, while about one-third (28\%) fetched the dung from distances $>3 \mathrm{~km}$. All dung was stored in unprotected (un-roofed) heaps before application, which usually occurred within 23 days (69\%) after the dung had been brought to the garden. In most gardens, the dung was applied to the surface of plots after hoeing (93\%). The majority of farmers (97\%) applied the dung during the cooler parts of the day, that is during mornings or/and evenings.

\section{Discussion}

The decrease in gaseous emissions over the duration of the experiment was slower for $\mathrm{C}$ than for $\mathrm{N}$, with 

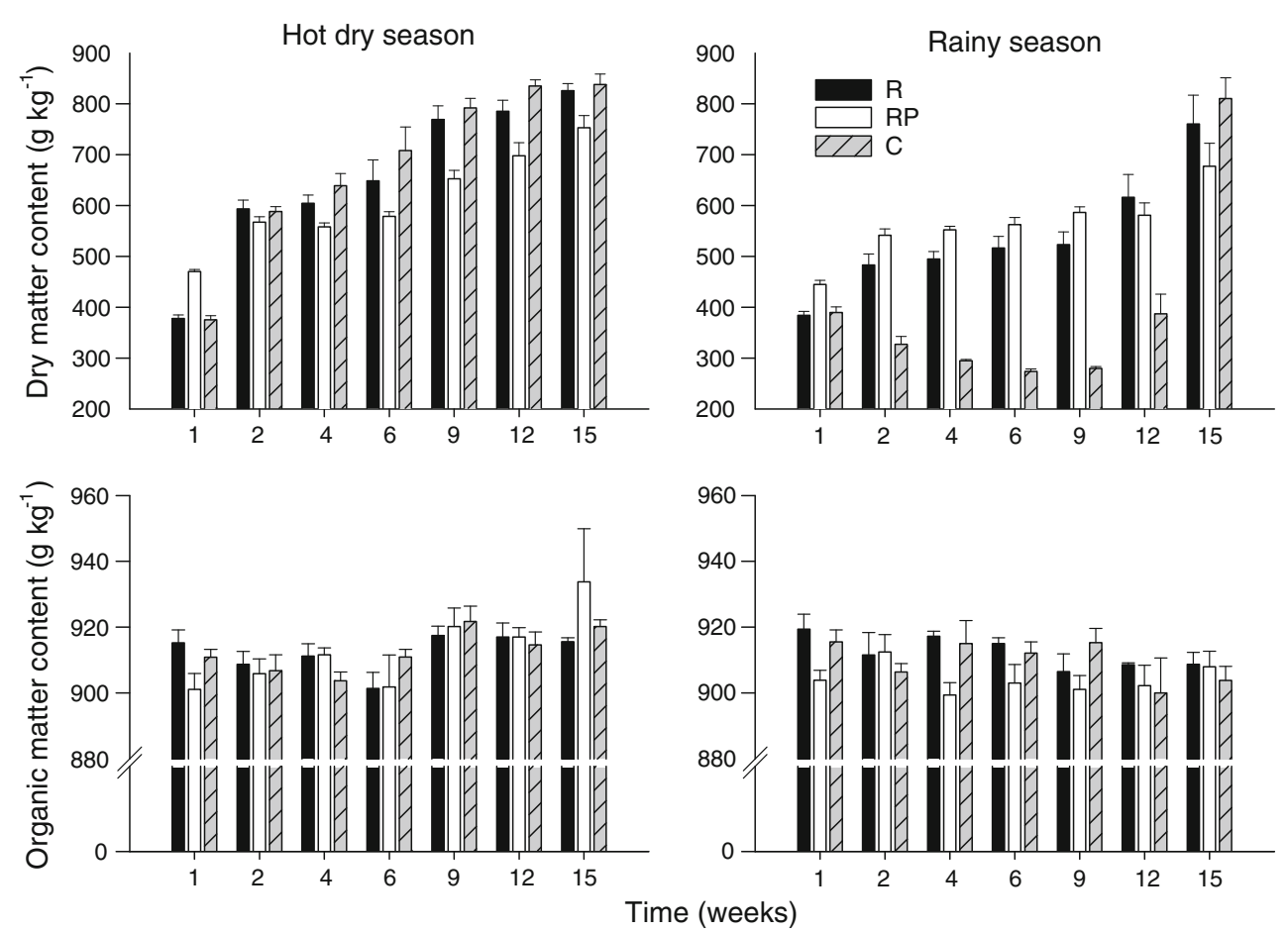

Fig. 6 Moisture and organic matter content of animal manure (dung) incubated in nylon litter bags during the hot dry and rainy season 2007 in Niamey, Niger. Data show means $(n=4)$ and one standard error of the untreated control treatment $(C)$, dung protection by a plastic roof $(\mathrm{R})$ and roof-protection combined with the addition of $333 \mathrm{~g}$ finely ground rock phosphate (RP) $\mathrm{kg}^{-1}$ manure DM
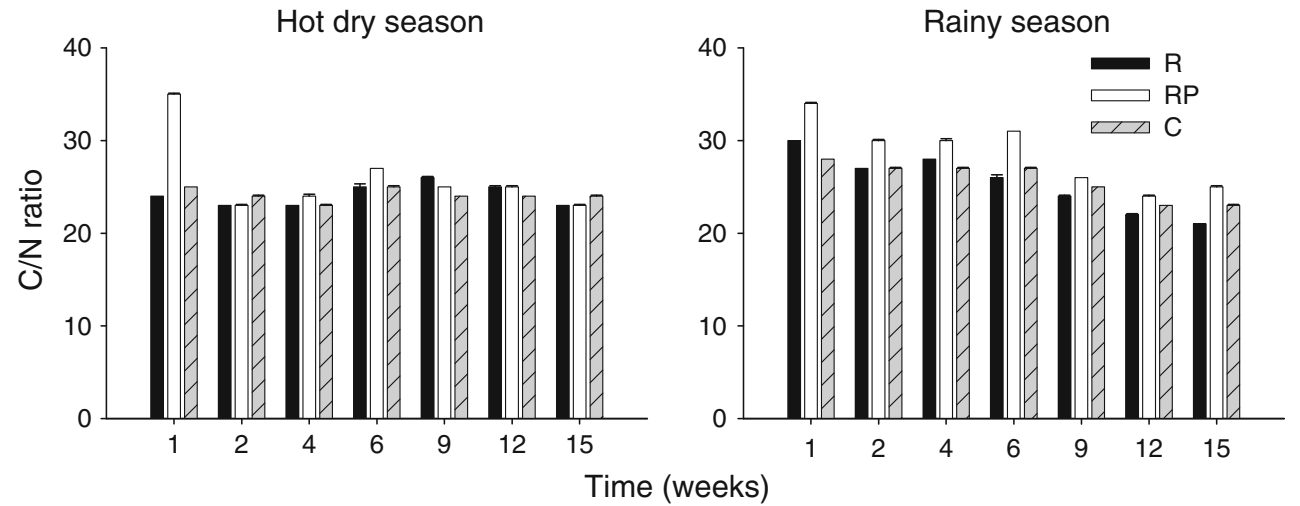

Fig. $7 \mathrm{C} / \mathrm{N}$ ratio of animal manure (dung) incubated in nylon litter bags during the hot dry and rainy season 2007 in Niamey, Niger. Data show means $(n=4)$ and one standard error of the

the exception of the $\mathrm{CH}_{4}-\mathrm{C}$ efflux in the control treatment during the rainy season (Fig. 3). The surprisingly high afternoon flux rates in weeks 1,4 and 6 in the rainy season might have been caused by concomitant rainfall events leading to temporarily untreated control treatment $(\mathrm{C})$, dung protection by a plastic roof $(\mathrm{R})$ and roof-protection combined with the addition of $333 \mathrm{~g}$ finely ground rock phosphate $\mathrm{kg}^{-1}$ manure DM (RP)

anaerobic conditions in the unroofed dung heaps and favourable conditions for methane producing bacteria (Gupta et al. 2007).

Our results of high gaseous $\mathrm{N}$ losses immediately after dung storage on heaps confirm similar data of 
Sommer (2001) and Sommer and Dahl (1999). These authors reported that during the composting of litter significant $\mathrm{NH}_{3}-\mathrm{N}$ emissions only occurred during the first 10 days of the experiments and accounted for $1.5 \%$ of the total initial $\mathrm{N}$ content in the substrate. This figure is similar to the total $\mathrm{N}$ losses from treatments $\mathrm{C}$ and $\mathrm{R}$ in our experiments, which during the hot dry season ranged from 1.3 to $1.8 \%$ of total $\mathrm{N}$ in the dung heaps. Ammonia emissions were the predominant form of $\mathrm{N}$ losses (Rufino et al. 2006) and were responsible for 87,69 and $91 \%$ of the total volatilized $\mathrm{N}$ for treatments $\mathrm{R}, \mathrm{RP}$ and $\mathrm{C}$, respectively. Lower storage losses of $\mathrm{N}_{2} \mathrm{O}-\mathrm{N}$ than of $\mathrm{NH}_{3}-\mathrm{N}$ were also reported by Oenema et al. (2007), Külling et al. (2003) and Sommer (2001). Similarly to our observations, Hellmann et al. (1997) reported $\mathrm{N}_{2} \mathrm{O}$ production during the first few days of their composting experiment to depend on the availability of $\mathrm{NH}_{3}$ as a substrate for nitrification. According to Sommer (2001) and Hellmann et al. (1997), the subsequent increase of substrate temperature inhibited the nitrification and de-nitrification through thermophobic microorganisms. In contrast to their results, the $\mathrm{N}_{2} \mathrm{O}-\mathrm{N}$ emissions in our experiment did not increase later on and from the second experimental week onwards the temperatures in the top $0.1 \mathrm{~m}$ of the substrate remained between $33-40^{\circ} \mathrm{C}$ and $29-32^{\circ} \mathrm{C}$ during the hot dry and the rainy season, respectively. This might be due to the warm climatic conditions in which our experiment was conducted.

In both seasons the addition of ground RP decreased cumulative $\mathrm{N}$ losses to $0.1 \%$ of the total initial $\mathrm{N}$ stock, which may be due to $\mathrm{N}$ absorption by the large surfaces of the fine RP particles. Such effects of finely ground minerals on $\mathrm{NH}_{3}-\mathrm{N}$ emissions during composting were previously reported by Zaied and Van den Weghe (2000). In contrast, RP application did only have minor effects on gaseous $\mathrm{C}$ fluxes which reached a total of $15-20 \%$ of the initial $\mathrm{C}$ content in the hot dry season and $24-36 \%$ in the rainy season. The latter losses are several-fold higher than the $10 \% \mathrm{C}$ loss reported from a composting of diary cows deep litter during the winter months in Denmark by Sommer and Dahl (1999). This may have been due to the prolonged storage of the manure (Table 1) under more favourable conditions for ruminant dung decomposition under the hot and wet weather conditions of the Sahelian rainy season (Esse et al. 2001).
For our experiments, the mixture of manure from small ruminants and cattle as typically used by local farmers (Table 1) was brought fresh (1-2 days old) from the stables of urban livestock keepers. Large gaseous $\mathrm{N}$ and $\mathrm{C}$ losses are likely to occur immediately after manure spreading: Sommer and Hutchings (2001) reported that $50 \%$ of the total $\mathrm{NH}_{3}-\mathrm{N}$ was volatilized during the first $24 \mathrm{~h}$ after application. The results of our interview show that more than half of the farmers $(51 \%)$ transported the animal manure from a distance bigger than $1 \mathrm{~km}$ every 2 or 4 weeks (Table 1) which resulted in prolonged storage under unroofed conditions. Carbon and $\mathrm{N}$ losses that occurred immediately after manure deposition at the farms, during dung mixing, loading at the farm gate, transport to and storage in UPA garden areas (Hao et al. 2001; Sommer 2001) were not measured, therefore the real $\mathrm{N}$ and $\mathrm{C}$ losses along the entire manure management chain will have been much higher that estimated in our study.

The results showed that the use of a simple plastic roof effectively eliminated leaching losses of $\mathrm{K}$ and $\mathrm{C}$ during the rainy season. Sommer (2001) reported cumulative $\mathrm{K}$ leaching losses from cattle manure storage during 132 days to range from 8 to $16 \%$ of the initial $\mathrm{K}$ content which is similar to the $16 \% \mathrm{~K}$ lost in our rainy season experiment (Table 2). The high $\mathrm{C}$ and $\mathrm{K}$ leaching losses measured in our study are likely to be representative for UPA gardens in Niamey as none of the interviewed farmer used any cover to protect manure storage heaps. In most years leaching losses may even be higher as during 2007 when total rainfall was with $371 \mathrm{~mm}$ much lower than the annual average of $542 \mathrm{~mm}$.

In SW Niger many studies have been conducted on how to alleviate the notoriously low $\mathrm{P}$ status of the dominant acid sandy soils (Bationo and Mokwunye 1991; Kretzschmar et al. 1991; Buerkert et al. 1998; Buerkert et al. 2001; Somado et al. 2003). While Squalli and Nadir (1983) suggested the use of soluble superphosphate for arid Moroccan market gardens, in Niamey the locally available inexpensive Tahoua RP (costs were $0.5 €$ per $10 \mathrm{~kg}$ in 2007) of which high agronomic efficiencies for on-farm millet fields were previously reported by Bationo et al. (1990), might present an effective way of increasing garden soil $\mathrm{P}$ stocks while decreasing $\mathrm{N}$ losses during dung storage.

Successful use of the closed chamber system with the photo-acoustic infrared INNOVA monitor has 
Table 1 Categorized results of an interview of 215 gardeners in 6 city quarters of Niamey, Niger (2007)

\begin{tabular}{|c|c|c|c|c|}
\hline \multirow{2}{*}{$\frac{\text { Question }}{\text { Nationality }}$} & \multicolumn{4}{|c|}{ Category (\% of total 215 gardeners) } \\
\hline & Niger & Burkina Faso & & \\
\hline & 31 & 69 & & \\
\hline \multirow[t]{2}{*}{ Ownership } & Owner & Rented & & \\
\hline & 29 & 71 & & \\
\hline \multirow[t]{2}{*}{ Cultivated area } & $<250 \mathrm{~m}^{2}$ & $251-750 \mathrm{~m}^{2}$ & $>751 \mathrm{~m}^{2}$ & \\
\hline & 51 & 45 & 4 & \\
\hline \multirow{2}{*}{$\begin{array}{l}\text { Area abandoned during hot dry } \\
\text { season }\end{array}$} & $<25 \%$ & $26-50 \%$ & $51-75 \%$ & $>75 \%$ \\
\hline & 8 & 57 & 24 & 11 \\
\hline \multirow[t]{2}{*}{ Chemical fertilizer use } & No use & Urea only & NPK only & Urea + NPK \\
\hline & 33 & 8 & 31 & 27 \\
\hline \multirow{2}{*}{$\begin{array}{l}\text { Animal dung use (several answers } \\
\text { possible) }\end{array}$} & Cattle & Small ruminants & & \\
\hline & 98 & 87 & & \\
\hline \multirow[t]{2}{*}{ Dung origin } & Purchased & From own animals & Both & \\
\hline & 69 & 3 & 28 & \\
\hline \multirow{2}{*}{$\begin{array}{l}\text { Frequency of dung import to the } \\
\text { garden }\end{array}$} & Every 1 week & Every 2 weeks & Every 4 weeks & Not regularly \\
\hline & 9 & 57 & 31 & 3 \\
\hline \multirow[t]{2}{*}{ Dung transport distance } & $<1 \mathrm{~km}$ & $1-3 \mathrm{~km}$ & $>3 \mathrm{~km}$ & \\
\hline & 49 & 23 & 28 & \\
\hline \multirow[t]{2}{*}{ Dung transport means } & Animals & People & Car & Combined \\
\hline & 13 & 27 & 25 & 35 \\
\hline \multirow{3}{*}{$\begin{array}{l}\text { Person responsible for the dung } \\
\text { transport }\end{array}$} & Gardner & Children & Hired labor & Gardner + hired \\
\hline & 25 & 2 & 43 & labor \\
\hline & & & & 30 \\
\hline \multirow{3}{*}{$\begin{array}{l}\text { Duration of dung storage } \\
\text { in garden before application }\end{array}$} & Immediate & 1 day & $2-3$ days & 1 week \\
\hline & application & 26 & 69 & 1 \\
\hline & 4 & & & \\
\hline \multirow[t]{2}{*}{ Type of dung storage } & In heaps, unprotected & Covered & & \\
\hline & 100 & 0 & & \\
\hline \multirow[t]{2}{*}{ Dung application time } & Mornings & Evenings & Mornings or evenings & Any time \\
\hline & 26 & 14 & 57 & 3 \\
\hline \multirow[t]{3}{*}{ Type of dung application } & On the surface & On the surface & Incorporated into the & \\
\hline & 6 & after hoeing & topsoil & \\
\hline & & 93 & 1 & \\
\hline \multirow{3}{*}{$\begin{array}{l}\text { Reason for using animal manure } \\
\text { (several answers possible) }\end{array}$} & Cheap & Accessible & Good growth/harvest & Own animals' \\
\hline & 32 & 3 & of crops & supply \\
\hline & & & 98 & 2 \\
\hline
\end{tabular}

been reported in earlier studies measuring gaseous emissions from a range of soils. The most critical factor determining the reliability of the method in hot environmental conditions seems to be the length of the gas accumulation period. In the literature reported accumulation periods range from 2 to $3 \mathrm{~min}$ (Hans et al. 2005; Reth et al. 2005) until $1 \mathrm{~h}$ (Velthof et al.
2003; van Groenigen et al. 2005). Because in our study the rapid increase in gas concentration, the raise in temperature and the built-up of humidity in the cuvette, especially during the midday measurements, influenced emission fluxes (feed back mechanisms), we have shortened the accumulation period to $1 \mathrm{~min}$. 
Table 2 Cumulative gaseous and leaching losses (in absolute terms and as a proportion of the total initial C, N, P and K content) from three different dung storage treatments $(n=4 /$ treatment $)$ during the hot dry and rainy season 2007 in Niamey, Niger

\begin{tabular}{|c|c|c|c|c|c|c|c|c|c|c|c|c|c|}
\hline \multirow[t]{2}{*}{ Season } & \multirow[t]{2}{*}{ Treatment } & \multicolumn{4}{|c|}{ Cumulative gaseous losses } & \multicolumn{8}{|c|}{ Cumulative leaching losses } \\
\hline & & $\begin{array}{l}\mathrm{N} \\
(\mathrm{g} 1\end{array}$ & $\begin{array}{l}\text { C } \\
\text { lays }^{-1} \text { ) }\end{array}$ & $\begin{array}{l}\mathrm{N} \\
(\% \mathrm{C}\end{array}$ & $\begin{array}{l}\text { C } \\
\text { content) }\end{array}$ & $\begin{array}{l}\text { C } \\
\text { (g } 10\end{array}$ & $\begin{array}{l}\mathrm{N} \\
\text { days }\end{array}$ & P & $\mathrm{K}$ & $\begin{array}{l}\mathrm{C} \\
(\%\end{array}$ & $\begin{array}{l}\mathrm{N} \\
\text { initia }\end{array}$ & $\begin{array}{l}\mathrm{P} \\
\text { content) }\end{array}$ & $\mathrm{K}$ \\
\hline \multirow[t]{3}{*}{ Hot dry } & Roof & 2.3 & 2,759 & 1.3 & 20.1 & & & & & & & & \\
\hline & Roof $+\mathrm{P}$ & 1.6 & 2,039 & 0.1 & 15.1 & & & & & & & & \\
\hline & Control & 3.2 & 2,193 & 1.8 & 16.1 & 7.3 & 0.2 & 0.5 & 5.0 & 0.1 & 0.0 & 0.3 & 1.2 \\
\hline \multirow[t]{3}{*}{ Rainy } & Roof & 1.0 & 3,793 & 0.7 & 27.5 & & & & & & & & \\
\hline & Roof $+\mathrm{P}$ & 1.2 & 3,201 & 0.1 & 23.6 & & & & & & & & \\
\hline & Control & 1.5 & 4,904 & 0.9 & 35.7 & 64.1 & 1.4 & 2.0 & 53.3 & 0.5 & 0.3 & 1.2 & 16.0 \\
\hline
\end{tabular}

\section{Conclusions}

During the hot dry season a simple plastic sheet roofing and addition of ground RP to stored ruminant manure decreased total $\mathrm{N}$ gaseous losses by $50 \%$ in comparison to dung directly exposed to the sun. In absolute terms these $\mathrm{N}$ losses were rather small which was most likely due to the fact that during the transfer of the manure from the stable to the dung heap much of the easily mineralizable and mineral $\mathrm{N}$ has already been lost. Plastic roofing also protected dung heaps from leaching losses during the rainy season. In order to decrease $\mathrm{N}$ volatilization from dung heaps and simultaneously increase $\mathrm{P}$ stocks in garden soils, the addition of finely ground RP to dung heaps proved particularly effective.

A closer linkage between animal keepers and gardeners and increased awareness of simple and locally accessible techniques to reduce volatilization and leaching losses of $\mathrm{C}$ and $\mathrm{N}$ from manure heaps may help to increase the nutrient use efficiency in UPA gardens across the Sahel.

Acknowledgments We are indebted to Rainer Georg Joergensen for his helpful advice, to Issa Karimou, Claudia Thieme and Eva Wiegard for technical assistance, to ICRISAT Sahelian Centre and EIRENE for logistical support and to the Deutsche Forschungsgemeinschaft (DFG) for funding.

Open Access This article is distributed under the terms of the Creative Commons Attribution Noncommercial License which permits any noncommercial use, distribution, and reproduction in any medium, provided the original author(s) and source are credited.

\section{References}

Asomani-Boateng R (2002) Urban cultivation in Accra: an examination of the nature, practices, problems, potentials and urban planning implications. Habitat Int 26:591-607

Backhaus K, Erichson B, Plinke W, Weiber R (2003) Multivariate Analysemethoden-Eine anwendungsorientierte Einführung. Springer, Berlin

Bationo A, Mokwunye AU (1991) Alleviating soil fertility constrains to increased crop production in West Africa: the experience in the Sahel. Fertilizer Res 29:95-115

Bationo A, Chien SH, Henao J, Christianson CB, Mokwunye AU (1990) Agronomic evaluation of two unacidulated and partially acidulated phosphate rocks indigenous to Niger. Soil Sci Soc Am J 54:1772-1777

Binns JA, Maconachie RA, Tanko AI (2003) Water, land and health in urban and peri-urban food production: the case of Kano, Nigeria. Land Degrad Dev 14:431-444

Bryld E (2003) Potentials, problems, and policy implications for urban agriculture in developing countries. Agric Hum Values 20:79-86

Buerkert A, Haake C, Ruckwied M, Marschner H (1998) Phosphorus application affects the nutritional quality of millet grain in the Sahel. Field Crops Res 57:223-235

Buerkert A, Bationo A, Piepho HP (2001) Efficient phosphorus application strategies for increased crop production in sub-Saharan West Africa. Field Crops Res 72:1-15

Cofie OO, van Veenhuizen R, Drechsel P (2003) Contribution of urban and peri-urban agriculture to food security in Subsaharan Africa. Africa session of 3rd WWF, Kyoto, Japan

Drechsel P, Quansah C, Penning De Vries F (2005). Stimulation of urban and peri-urban agriculture in West Africa: characteristics, challenges, need for action. In: Smith OB (ed) Urban agriculture in West Africa. Contributing to food security and urban sanitation. International Development Research Centre (IDRC), Technical Centre for Agricultural and Rural Cooperation (ACP-EU) Ottawa, Canada and Wageningen, Netherlands

Ellis F, Sumberg J (1998) Food production, urban areas and policy responses. World Dev 26:213-225 
Esse PC, Buerkert A, Hiernaux P, Assa A (2001) Decomposition of nutrient release from ruminant manure on acid soils in the Sahelian zone of Niger, West Africa. Agric Ecosyst Environ 83:55-63

Ezedinma C, Chukuezi C (1999) A comparative analysis of urban agricultural enterprises in Lagos and Port Harcourt, Nigeria. Environ Urban 11:135-146

FAO-IFA (2001) Global estimated of gaseous emissions of $\mathrm{NH}_{3}, \mathrm{NO}$, and $\mathrm{N}_{2} \mathrm{O}$ from agricultural land. Rome, FAO of UN, International Fertilizer Industry Association

Graefe S, Schlecht E, Buerkert A (2008) Opportunities and challenges of urban and peri-urban agriculture in Niamey, Niger. Outlook Agric 37(1):47-56

Gupta PK, Jha AK, Koul S, Sharma P, Pradhan V, Gupta V, Sharma C, Singh N (2007) Methane and nitrous oxide emission from bovine manure management practices in India. Environ Pollut 146:219-224

Hans L, Buerkert A, Fuchs D, Golombek SD, Michel K, Brandt M, Hensel O (2005) Vertical nutrient fluxes in a traditional mountain oasis of northern Oman. Conference on international agricultural research for development, Tropentag 2005, Stuttgart-Hohenheim, Germany

Hao X, Chang C, Larney FJ, Travis GR (2001) Greenhouse gas emissions during cattle feedlot manure composting. J Environ Qual 30:376-386

Hellmann B, Zelles L, Palojarvi A, Bai Q (1997) Emissions of climate-relevant trace gases and succession of microbial communities during open-windrow composting. Appl Environ Microbiol 63(3):1011-1018

Houba VJG, van der Lee JJ, Novozamsky I (1995) Soil analysis procedures, other procedures. (Soil and plant analysis, Part 5B). Department of Soil Science and Plant Nutrition/ Wageningen Agricultural University, Netherlands

Howorth C, Convery I, O'Keefe P (2001) Gardening to reduce hazard: urban agriculture in Tanzania. Land Degrad Dev 12:285-291

Kauppinen J, Wilcken K, Kauppinen I, Koskinen V (2004) High sensitivity in gas analysis with photoacoustic detection. Microchem J 76(1-2):151-159

Kretzschmar RM, Hafner H, Bationo A, Marschner H (1991) Long- and short-term effects of crop residues on aluminum toxicity, phosphorus availability and growth of pearl millet in acid sandy soil. Plant Soil 136:215-223

Külling DR, Menzi H, Sutter F, Lischer P, Kreuzer M (2003) Ammonia, nitrous oxide and methane emissions from differently stored manure derived from grass- and haybased rations. Nutr Cycl Agroecosyst 65:13-22

Madaleno I (2000) Urban agriculture in Belém, Brazil. Cities $17: 73-77$

Matagi SV (2002) Some issues of environmental concern in Kampala, the capital city of Uganda. Environ Monit Assess 77:121-138

Maxwell D (1995) Alternative food security: a household analysis of urban agriculture in Kampala. World Dev 23:1669-1681

McClellan GH, Notholt AJG (1986) Phosphate deposits of tropical sub-Saharan Africa. In: Mokwunye AJG, Vlek PLG (eds) Management of nitrogen and phosphorus fertilisers of sub-Saharan Africa. Martinus Nijhoff, Dordrecht, pp 173-223

Oenema O, Oudendag D, Velthof GL (2007) Nutrient losses from manure management in the European Union. Livest Sci 112:261-272

Predotova M, Gebauer J, Diogo RVC, Schlecht E, Buerkert A (2010) Gaseous nitrogen and carbon emissions from urban gardens in Niamey, Niger. Field Crops Research (accepted)

Reth S, Hentschel K, Drösler M, Falge E (2005) DenNitexperimental analysis and modelling of soil $\mathrm{N}_{2} \mathrm{O}$ efflux in response on changes of soil water content, soil temperature, soil $\mathrm{pH}$, nutrient availability and the time after rain event. Plant Soil 272:349-363

Rufino MC, Rowe EC, Delve RJ, Giller KE (2006) Nitrogen cycling efficiencies through resource-poor African croplivestock systems. Agric Ecosyst Environ 112:261-282

Somado EA, Becker M, Kuehne RF, Sahrawat KL, Vlek PLG (2003) Combined effects of legumes with rock phosphorus on rice in West Africa. Agron J 95:1172-1178

Sommer SG (2001) Effect of composting on nutrient loss and nitrogen availability of cattle deep litter. Eur J Agron 14:123-133

Sommer SG, Dahl P (1999) Nutrient and carbon balance during the composting of deep litter. J Agric Eng Res 74:145-153

Sommer SG, Hutchings NJ (2001) Ammonia emission from field applied manure and its reduction—invited paper. Eur J Agron 15:1-15

Squalli A, Nadir M (1983) Nutrient dynamics in arid and semiarid areas-phosphate. In: Proceedings of the 17th colloquium of the international potash institute, Rabat, Marrakech (Morocco)

Truong B, Pichot J, Beunard P (1978) Caractérisation et comparaison des phosphates naturels tricalciques d'Afrique de l'Ouest en vue de leur utilisation directe en agriculture. Agronomie Tropicale 33:136-145

van Groenigen JW, Velthof GL, van der Bolt FJE, Vos A, Kuikman PJ (2005) Seasonal variation in $\mathrm{N}_{2} \mathrm{O}$ emissions from urine patches: effects of urine concentration, soil compaction and dung. Plant Soil 273:15-27

van Reeuwijk LP (1993) Procedures for soil analyses, technical paper No. 9, 4th edn. International Soil Reference and Information Centre (ISRIC), Wageningen, The Netherlands

Van Straaten P (2002) Rocks for crops: agrominerals of subSaharan Africa. ICRAF, Nairobi, Kenya, 338 pp

Velthof GL, Kuikman PJ, Oenema O (2003) Nitrous oxide emission from animal manures applied to soil under controlled conditions. Biol Fertil Soils 37:221-230

World Climate (2008) Accessed in October 2008 from www.worldclimate.com

Zaied H, Van den Weghe H (2000) Emissionen umweltrelevanter Gase bei der Kompostierung von Reststoffen aus der Legehennenhaltung mit mineralischem Zusatz in einem zwangsbelüfteten Reaktor. Müll und Abfall 2

Zhang G, Strøm JS, Li B, Rom HB, Morsing S, Dahl P, Wang C (2005) Emission of ammonia and other contaminant gases from naturally ventilated dairy cattle buildings. Biosyst Eng 92(3):355-364 